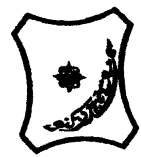

Bayero Journal of Pure and Applied Sciences, 9(2): 86 - 89

Received: January, 2016

Accepted: June, 2016

ISSN $2006-6996$

\title{
PREVALENCE OF FASCIOLOSIS AMONG CATTLE SLAUGHTERED AT HADEJIA ABATTOIR
}

\author{
${ }^{* 1}$ Abubakar, S., ${ }^{2}$ Yunusa, I. ${ }^{3}$ Ahmad, M. K., ${ }^{4}$ Abdullahi, M. K, ${ }^{5}$ Ibrahim, I., ${ }^{6}$ Zakariya, M. and \\ ${ }^{1}$ Yusuf, D. \\ ${ }^{* 1}$ Department of General Studies, Binyaminu Usman College of Agriculture, P.M.B. 013 Hadejia \\ ${ }^{2}$ Department of Biochemistry, Kano University of Science and Technology, P.M.B. 3244 Kano. \\ ${ }^{3}$ Department of Biological Sciences, Bayero University, Kano P. M. B 3011, Kano \\ ${ }^{4}$ School of hygiene Kano \\ ${ }^{5}$ Department of Hospital Services, Gundima Health System Board, Hadejia. \\ ${ }^{6}$ Department of Environmental Management, Bayero University, Kano P. M. B 3011, Kano \\ *Correspondence email: abubakar0736@gmail.com, Phone No. 080-3051 3210
}

\begin{abstract}
A study was carried out to find out the prevalence of Fasciolosis in cattle slaughtered at Hadejia Abattoir. Fasciola gigantica is a parasite of liver and bile duct in cattle, sheep and goat. The liver was examined for Fasciola by making length wise incision on the ventral side of the liver in such a way that the Bile duct was cut open. The forcep was used to pick the exposed worms in the bile duct and the Gall bladder. The Flukes recovered from each cattle were placed in label containers and taken to the Laboratory for identification and preservation. A total of 545 cattle were examined for the presence or absence of Fasciolosis in Hadejia Abattoir. Out of this number 279 (51.2\%) were males and 266 (48.8\%) were females. The overall prevalence of Fasciolosis in the study area was 159(28.0\%). The prevalence of Fasciolosis in males was found to be $73(26.2 \%)$, while the prevalence in females was $79(29.7 \%)$. There was no significant relationship $(P>0.05)$ between sex of the cattle and prevalence of the infection. The Prevalence of Fasciolosis in adult cattle was $36(40.2 \%)$, while in young cattle the prevalence was $123(15.0 \%)$. There was significant relationship ( $P<0.05)$ between the age of cattle and prevalence of the infection.Fasciolosis is one of the helminths diseases that were found to be prevalent affecting cattle in the study area.
\end{abstract}

Key words; Abattoir, Cattle, Cross-sectional., Fasciolosis, Slaughter,

\section{INTRODUCTION}

Fasciolosis is defined as the parasitic disease primarily on ruminant particularly cattle, sheep and goat and is found all over the World (Ajayi, 1987). Fasciola gigantica is a parasite of liver and bile duct in cattle, sheep, goat and wild ruminant in Africa and Asia. Fasciolosis in cattle, account for considerable economic loss(Ukoli, 1990).

Meat derived from cattle, sheep and goat provide major source of animal protein for the populace of Nigeria. These ruminants incidentally serve as a definitive host to the parasitic helminths, trematode of the family Faciolidae, commonly known as liver flukes. There are various species, but the economically important ones are $F$. gigantica in the tropical region and $F$. hepatica of the temperate region (Ikeme and Obioha, 1973).F. gigantica measure 4 to $10 \mathrm{~cm}$ in length.

The infection is wide spread throughout the world. Fasciolosis is endemic in 61 countries and has becomes a food-borne infection of public health importance in many parts of the world such us Anden Highland of Bolivia, Equador, Peru, Nile Delta of Egypt and Northern Iran. It is estimated that more than 180 million people are at risk of the infection (WHO, 1998). Thedistribution of species is limited to the tropic and is also found in African countries, Middle East, Eastern Asia and Eastern Europe (Tgerson, and Cloxton, 1919).Nigeria prevalence of Fasciolosis has been reported from different parts of the country. There are also several reports on the prevalence, regional incidence, and seasonal variation for bovine Fasciolosis (Maurice, 1994). Biu, et al. (1989) reported prevalence of $80 \%$ from Zaria northwest and prevalence of $65 \%$ was reported by Schilborn, et al. (1980) in a study conducted to evaluate the number, seasonal variation, of bovine Fasciolosis at Ibadan municipal Abattoir. Fasciolais responsible for widespread morbidity in cattle characterized by weight loss, anaemia and hypoproteinamia (Troncy, 1998)). Fasciolosis causes substantial weight reduction in milk yield, condemnation of affected liver, decline production and productive performances, exposure of animal to other diseases due to secondary complications and cost of treatment expenses(Anne and Gray, 2006).Meats infected by these organisms are regularly condemned at inspection in abattoir/slaughter slab. It could be zoonotic, while constituting a major economic problem by lowering quality of affected organs. Human can accidentally ingest the eggs/ larvae and become infected (Biu, et al., 2006). 
The present study was aimed at estimating the prevalence of Fasciolosis in cattle slaughtered at Hadejia Abattoir as well as the prevalence of the disease in relation to sex, age and body condition.

\section{MATERIALS AND METHODS \\ Study Area}

Hadejia Local Government is located in the north eastern corner of Jigawa State. It lies between $9^{0} 37^{\prime} \mathrm{E}$ and $10^{\circ} 35^{\prime} \mathrm{E}$ Longitude and $13^{\circ} 02^{\prime} \mathrm{N}$ Latitude. The climate of the region is wet and dry type, rainfall spread between June to September with mean Annul rainfall of $315 \mathrm{~mm}$. The soil in the study area is sandy in nature except inFadama area that has clay soil (Wikipedia, 2000).

River Hadejia provide water for irrigation and fish production. People in the area are farmers that grow both rain fed and irrigated crops and some are animal rearers. Hadejia is a big city with many traders and business men and thus large numbers of cattle were slaughtered daily. Data from the Abattoir is useful for the identification of problems and may be used to reveal the prevalence, seasonal variation and economic importance of the parasitethat infect the slaughtered animals. Even though it does not avail any information regarding the development of the disease in live animal(Ekwenife, et al., 2006).

\section{Study Population}

A total of 545 cattle were examined for the presence or absence of Fasciolosis. The cattle are both young < 5 years and adult $\geq 5$ years of both sexes. In this study 305 were young and 240 were adult and were all indigenous.

\section{Parasitological Identification}

The study was carried out between January to March, 2013 in Hadejia Abattoir. The slaughter house was visited for two months, twice in every week. This was done between $6.00 \mathrm{am}$ to $10.00 \mathrm{am}$. This is the period when cattle are slaughtered in this area. The work involved actual post-mortem inspection of the liver on the cattle. The liver was examined for Fasciola by making length wise incision on the ventral side of the liver in such a way that the Bile duct was cut open. The Forcep was used to pick the exposed worms in the bile duct and the gall bladder. The Flukes recovered from each cattle were placed in labelled containers and taken to the Laboratory for identification and preservation (Yesmirach and Mekonen, 2012, Olusegun, et al., 2011).

\section{Statistical Analysis}

Chi square $\left(X^{2}\right)$ test was used to determine association between variables (prevalence, sex and age) and their degree of significance at $95 \%$ confidence interval.

\section{RESULTS}

Five hundred and forty five (545) cattle were examined in Hadejia Abattoir. Out of this number $279(51.2 \%)$ were males and $266(48.8 \%)$ were females (Table 1).

Table 2shows prevalence of Fasciolosis affecting cattle in relation to sex. Prevalence of the infection in males was found to be73(26.2\%), while prevalence of the infection in females was found to be $79(34.9 \%)$. There was no was significant relationship $(p>0.05)$ between the sex of cattle and prevalence of the infection. The overall prevalence of Fasciolosis was found to be $28.0 \%$.

Table-3 shows prevalence of Fasciolosis affecting cattle in relation to age. Prevalence of the infection in Adult was found to be $116(40.3 \%)$, while in young cattle prevalence of Fasciolosis was found to be $36(15 \%)$. There was significant relationship ( $p<$ 0.05 ) between the age of cattle and prevalence of the infection.

Table 1: Sex structure of the study population

\begin{tabular}{lll}
\hline SEX & NO. EXAMINED & PERCENTAGE (\%) \\
\hline MALE & 279 & 51.2 \\
FEMALE & 266 & 48.8 \\
\hline TOTAL & 545 & 100 \\
\hline
\end{tabular}

KEY:Values in parenthesis (\%) are percentage.

Table 2: Prevalence of Fasciolosis in cattle in relation to sex

\begin{tabular}{llll}
\hline SEX & NO. EXAMINED & NO. INFECTED & PERCENTAGE (\%) \\
\hline MALE & 279 & 73 & 26.2 \\
FEMALE & 226 & 79 & 34.9 \\
\hline OVERALL & 545 & 152 & 28.0 \\
\hline
\end{tabular}

There was no significant relationship ( $p>0.05$ ) between the sex of cattle and prevalence of the infection.

Table-3: Prevalence of Fasciolosis affecting Cattle in relation to age

\begin{tabular}{llcl}
\hline SEX & NO. EXAMINED & NO. INFECTED & PERCENTAGE \\
\hline ADULT & 305 & 116 & 40.3 \\
YOUNG & 240 & 36 & 15.0 \\
\hline TOTAL & 545 & 152 & 28.0 \\
\hline
\end{tabular}

There was significant relationship $(p<0.05)$ between the age of cattle and prevalence of the infection. 


\section{DISCUSSION}

The result of this study indicates that Fasciolosis was prevalent in the study area. The reason for this prevalence could be due to increase in irrigated land masses in the study areaand tendency for animal rearers and farmers to feed the animals in these marshy and damp arrears because of feed scarcity. Since intermediate host prefers swampy arrears with slowly moving water and small streams which also allow sufficient moisture for the survival of the infective metacercariae (Magaji, et al., 2014).

The result of this study is in close agreement with the finding of Yesmirach and Mekonen (2012), who reported prevalence of Fasciolosis in cattle as $28.6 \%$. Similarly this work closely agrees with the work of Abebe, et al. (2011), who reported prevalence of Fasciolosis to be 29.1\%.Oladeleke andOdetokun(2014) reported $37.8 \%$ prevalence of bovine Fasciolosis at Ibadan Municipal abattoir;this value is higher than the value reported in the present work.Biniam, et al. (2012) reported 41.41\% prevalence in a study of bovine Fasciolosis in and around Woreta,NorthwesternEthiopia, which is higher than the value of the present work.Ekwenife, et al. (2006), in Onitsha Abattoir reported prevalence of $10.51 \%$, which is much lower than the value obtained in the present study, also Kasseye and Yehualashet (2012), reported prevalence of $20.3 \%$. This value is lower than the value obtained in the present study. The differences among the geographical locations could be attributed mainly due to the variation in the climatic and ecological conditions such as altitude, rainfall and temperature. The ecological condition is favourable for the survival and development of the snail intermediate host for specie of Fasciola (Kasseye and Yehualashet, 2012).

The prevalence of Fasciolosis among both sexes did not differ significantly in males $(26.2 \%)$ and in females $(29.7 \%)$. This value shows that Fasciolosis is not gender specific disease, rather it occur due exposure of the animal to the contaminated posture. The work in the present study is in conformity with the work of Mebrahtu and Beka (2013) that worked on prevalence and economic significance of Fasciolosis in cattle slaughtered at Dire Municipal abattoir, Ethiopia which reported higher prevalence in female $(25.27 \%)$ than male $(23.9 \%)$. The work in the Present study disagree with the work of Magaji, et al. (2014) that worked on prevalence of Fasciolosis in cattle slaughtered at Sokoto metropolitan abattoir, who reported higher prevalence in males $27(28.42 \%)$ than female $35(27.13 \%)$.Similarly the work of Biniam, et al. (2012) also disagrees with the present work,

\section{REFERENCES}

Abebe, F. B.,Meharenet, and Mekebib, B.(2011). Major Fasciolosis Infections of cattle Slaughtered at Jimma Municipality Abattoir and the occurance of the intermediate Host in selected water bodies of the Zone.Published by Journal of Animal and which reported higher prevalence in males (41.43\%) than female $(41.38 \%)$.

The prevalence of Fasciolosis in adult cattle was found to be greatly higher $(40.3 \%)$ than young ones $(15.0 \%)$. This assertion is in conformity with the work of Yesmirach and Mekonen (2012), in their finding the prevalence was significantly higher in adult cattle (39.8\%) than in young cattle $(23.3 \%)$. The present report contradicts the work of Mebrahtu and Beka (2013) that reported higher prevalence in young $(19.63 \%)$ than adult $(25.95 \%)$. This could be explained by the fact that younger animals are usually kept in door or around home and are not allowed to go far with adult animals for grazing so that they have reduced chance of exposure to infective posture when compared with adult Yesmirach and Mekonen, 2012).

\section{CONCLUSION}

Fasciolosis is a helminths disease that was found to be prevalent affecting cattle in the study area. The prevalence of Fasciolosis did not differ in males and females. Therefore, the disease has no gender sensitivity but was found to affect mostly adult, because of exposure to contaminated herbage.

\section{Authors Contribution}

Abubakar, S. and Yunusa,I.designed the study and are involved in statistical analysis. Ahmed, M. K. and Abdullahi, M. K assisted in data collection, Abubakar, S. and Ibrahim, I. were involved in data analysis. Abubakar, S. and Zakariya, M. were involved in writing up the manuscript.

\section{Conflict of Interests}

The authors of this study declare that there was no conflict of interest related to the present work.

\section{Acknowledgement}

The authors wish to thank management of Hadejia Abattoir and other veterinary staff of the Abattoir for their unreserved support during data collection.

\section{Recommendations}

- Government should improve services of veterinary personnel in order improve health of the animal.

- Veterinary inspectors should improve meat inspection and government should pay compensation of condemn meat.

- Nomadic education should be improved in order to enlighten pastoralist, to learn advantage of intensive or semi intensive farming rather than the traditional extensive farming.

Veterenary Parasitology Advances, Vol. 10, $1597-1605$.

Ajayi, T.A. (1987).Prevalence of Liver Helminths Parasites of Ruminant in Maiduguri, Borno State, Bulletin of Animal Health and Production,25 - 33. 
BAJOPAS Volume 9 Number 2 December, 2016

Aunn, M. Z. and Gray, M.C. (2006). Veterinary Clinical Parasitology, $7^{\text {th }}$ Ed, American Association of Parasitology, $185-210$.

Biniam, T., Hanna, A. and Sisay, G (2012). Study on Coprological Prevalence of Bovine Fasciolosis in and around Woreta, North-western Ethiopia. Journal of Veterinary Medicine and Animal Health, Volume 4(7):89 - 92.

Biu, A. A. Ahmed, M.I. and Mschelia, S.S. (2006).Economic Importance of Bovine Fasciolosis in Nigeria. Tropical Animal Health and Production, Vol. 12, No. 3, $155-160$.

Ekwenife, Chinyelu, A. and Eneanya, C. I. (2006). Fasciola gigantica in Onisha, Environs Animal Research International,3 (2), 448 450.

Ikeme and Obioha. (1973). Fasciola Gigantica Infestation in Trade Cattle in Eastern Nigeria, Bulletin of Epizootic diseases in Africa, vol. 21, (3), $259-264$.

Kasseye, A., Yehualashet, B., Yilfat., D. and Desie, S. (2012). Fasciolosis in Slaughtered cattle in Adis-Ababa Abattoir.Published by Global Veterenaria, 8(2), $115-118$.

Magaji, A.A., Kabir, I.,Salihu, M.D., Saulawa, M.A., Muhammed, A.A. and Musawa, A. I. (2014). Prevalence of Fasciolsis in Cattle Slaughtered in Sokoto Metropolitan Abattoir, Sokoto, Nigeria.Advance in Epidemiolgy, Vol. 4, 10 15.

Mebrahtu, G. and Beka, K. (2013). Prevalence and Economic Significance of Fasciolosis in Cattle Slaughtered at Dire Dawa Municipal Abattoir, Ethiopia. Journal of Veterinary Advance, 3(12):319- 324 .
Oladeleke, B. and Odetokun, I.A (2-14). Prevalence of Bovine Fasciolosis at the Ibadan Municipal Abattoir, Nigeria.African Journal of Agriculture, Nutrition and Development, Vol. 14, No. 4, $9055-9064$.

Olusegun, J. Doherty, V. F., and Edighagba, B. O. (2011). Prevalence of Fasciolosis in cattle Slaughtered at Zaria Abattor. Published by Jornal of Environmental Issues, Jevascs, 1, (1): 50- 56.

Schilborn, T.W. Folaranmi, D.O.B., Usman, S. and Ishaya (1980). Incidence of Liver fluke Infections ( $F$. gigantica) in Ruminants, Northern Nigeria.Nigerian Tropical Animal and Production, Vol. 12, No. 2, $97-104$.

Tgerson, P. and Cloxton, J. (1919). Epidemiology and Control of Fasciolosis, Pulished by WilligFordoxok, UK, 113 - 149.

Troncy, P.M. (1989). Helmithes of livestock and Poultry in Tropical Africa.Manual of Tropical Parasitology, CAP International, UK, 63 - 73.

Ukoli, E. M. A. (1990). Introduction to Parasitology in Tropical Africa, Publish by Tex Flow limited. Ibadan, Nigeria, 463 - 473.

Wikipedia.(2000). Post offices with Maps of the Local Government Areas.

World Health Organisation (1998).Triclbendazole and Fasciolosis. A New Drug to combat an age Disease. Fact Sheet, 191.

Yesmirach, A. and Mekonen,(2012). An Abattoir Study on the Prevalence of Fasciolosis in cattle, sheep and goat in Debrezeit Town, Ethiopia. Journal of Global Veterinaria, 8(3), 308 314. 